\title{
ORIGINAL MODEL FOR ESTIMATING THE WHOLE LIFE COSTS OF BUILDINGS AND ITS VERIFICATION
}

\author{
E. PLEBANKIEWICZ ${ }^{1}$, K. ZIMA ${ }^{2}$, D. WIECZOREK ${ }^{3}$
}

\begin{abstract}
The model for estimating the whole life costs of the building life cycle that allows the quantification of the risk addition lets the investor to compare buildings at the initial stage of planning a construction project in terms of the following economic criteria: life cycle costs (LCC), whole life costs (WLC), life cycle equivalent annual costs $(\mathrm{LCEAC})$ and cost addition for risk $\left(\Delta \mathrm{R}_{\mathrm{LCC}}\right)$. The subsequent stages of the model development have been described in numerous publications of the authors, while the aim of this paper is to check the accuracy of the model in the case of changing the parameters that may affect the results of calculations. The scope of the study includes: comparison of the results generated by the model with the solutions obtained in the life cycle net present value method (LCNPV) for time and financial input data, not burdened with the risk effect; the analysis of the variability of results due to changes in input data; analysis of the variability of results as a consequence of changing the sets of membership functions for input data and methods for defuzzification the result.
\end{abstract}

Keywords: life cycle costs, whole life costs, life cycle equivalent annual costs, cost addition for risk, risk, building

\section{INTRODUCTION}

Striving to minimize the costs related to the implementation of buildings is the subject of interest to every investor, while limiting the costs related to their use, maintenance and withdrawal (for instance, decommissioning by demolition) is not an issue that has been discussed in the past as often as today, as discussed in publications $[1,3,4,5,13,14]$.

\footnotetext{
${ }^{1}$ Prof., DSc., PhD., Eng., Cracow University of Technology, Faculty of Civil Engineering, Institute of Construction Management, 24 Warszawska street, 31-155 Cracow, Poland, e-mail: eplebank@L3.pk.edu.p1

2 DSc., PhD., Eng., Cracow University of Technology, Faculty of Civil Engineering, Institute of Construction Management, 24 Warszawska street, 31-155 Cracow, Poland, e-mail: kzima@L3.pk.edu.pl

${ }^{3} \mathrm{PhD}$., Eng., Cracow University of Technology, Faculty of Civil Engineering, Institute of Construction Management, 24 Warszawska street, 31-155 Cracow, Poland, e-mail: dwieczorek@L3.pk.edu.pl
} 
The issue of life cycle costs is part of the Sustainable Development Strategy, which is the special focus of attention of the European Union, and the integrated product approach (also referring to buildings) is currently considered as the most effective way to implement the environmental dimension of this strategy. Today's requirement that construction projects be economically and environmentally effective in their whole life cycle makes the issue of life cycle costs of buildings become an increasingly common element of comprehensive analyses which may involve the impact on the environment, energy consumption, society or the impact of risk $[2,6,8,9,11,15,16]$.

The authors have therefore attempted to develop a model for estimating the whole life costs of buildings enabling the quantification of cost addition for risk, which would allow the investor to compare buildings in terms of a number of economic criteria: life cycle costs (LCC - when the investor is not able to record incomes), whole life costs (WLC - when, in addition to bearing the costs during the life cycle of the building, the investor is able to record incomes), life cycle equivalent annual costs (LCEAC - when the durations of the operation phase differ) and cost addition for risk $\left(\Delta \mathrm{R}_{\mathrm{LCC}}\right.$ - expressed as a difference in currency units between the life cycle cost of a building which takes into account the impact of risk and the life cycle cost of a building that does not include this impact). The subsequent stages of the development of the model are described in numerous publications by the authors $[10,11,12,13,17,19]$.

The aim of this paper is, however, to check the accuracy of the model in estimating the whole life costs of buildings in the case of changing parameters that may affect the results of calculations. The scope of the research includes: comparison of the results generated by the model with the results obtained by the net present value in the life cycle (LCNPV) for the time and financial input data not influenced by risk; analysis of variability of results due to changes in input data; analysis of the variability of results as a result of changing sets of membership functions for input data and methods for defuzzification the result.

\section{ORIGINAL MODEL FOR ESTIMATING THE WHOLE LIFE COSTS OF BUILDINGS}

In the model of estimating the whole life cost of the building that allows the quantification of the risk addition, the theory of fuzzy sets is combined with the most common, dynamic method used to analyse the economic effectiveness of construction projects on the basis of discounted cash flows $(\mathrm{dCF})$. This is a net present worth method (NPW), also called net present value method (NPV), which in the model is applicable in the fuzzy version (fuzzy NPW method). The calculations in the 
model are based on: the discounted cash flows (dCF) analysis at a specified discount rate (r) value; the net present worth (value) indicator which is the difference between discounted cash flows (dCF) and initial investments; the concept of fuzzy numbers; the theorem on decomposition of a fuzzy set into $\alpha$-cuts; Zadeh's extension principle.

A set of calculation formulas, thanks to which it is possible to calculate economic indicators: LCC, WLC, LCEAC and $\Delta \mathrm{R}_{\mathrm{LCC}}$, was presented and discussed in detail in the following authors' publications $[10,11,18,19]$. The examples below include only the most important equations. Equation (1.1) calculates the value of criterion LCC. Equation (1.2) is used to calculate incomes in the life cycle of the building (ILC). After the deduction of the LCC from ILC, the WLC criterion is established.

$$
\overline{L C C_{i}}=\overline{C_{i n, i}}+\overline{P W F_{A C, i}} \cdot \sum_{j=1}^{n_{A C, i}} \overline{C_{o p A, i j}}+\sum_{k=1}^{n_{N A C, i}} \overline{C_{o p N A, i k}} \cdot \overline{P W F_{N A C, i k}}+\overline{P W F_{W D, i}} \cdot \overline{C_{w d, i}}
$$

where:

$\mathrm{LCC}_{\mathrm{i}}$ - the amount of the life cycle costs of the i-th building, $\mathrm{C}_{\mathrm{in}, \mathrm{i}}-$ the amount of initial costs, $\mathrm{C}_{\mathrm{opA}, \mathrm{ij}}-$ the amount of the $\mathrm{j}$-th annual operating cost, $\mathrm{C}_{\mathrm{opNA}, \mathrm{ik}}-$ the size of the k-th periodic operational cost, $\mathrm{C}_{\mathrm{wd}, \mathrm{i}}-$ the amount of decommission costs, $\mathrm{n}_{\mathrm{AC}, \mathrm{i}}, \mathrm{n}_{\mathrm{NAC}, \mathrm{i}}-$ the respective number (multiplicity) of operating costs of an annual and periodic nature, $\mathrm{PWF}_{\mathrm{AC}, \mathrm{i}}$ - the value of the discount factor for annual operating costs, $\mathrm{PWF}_{\mathrm{NAC}, \mathrm{ik}}-$ the value of the discount factor for the $\mathrm{k}$-th periodic operational cost, $\mathrm{PWF}_{\mathrm{WD}, \mathrm{i}}$ - the value of the discount factor for revenue achieved in the decommission phase; the overline in the formula means that the given value is a fuzzy number.

$$
\overline{I L C_{i}}=\overline{P W F_{A I, i}} \cdot \sum_{l=1}^{n_{A I, i}} \overline{I_{o p A, i l}}+\sum_{m=1}^{n_{N A I, i}} \overline{I_{o p N A, i m}} \cdot \overline{P W F_{N A I, i m}}+\overline{P W F_{W D I, i}} \cdot \overline{I_{w d, i}}
$$

where:

$\mathrm{ILC}_{\mathrm{i}}$ - the amount of incomes in the life cycle of the i-th building, $\mathrm{I}_{\mathrm{opA}, \mathrm{il}}$ - the amount of the 1-th annual income, $\mathrm{I}_{\mathrm{opNAi}, \mathrm{m}}$ - the amount of the $\mathrm{m}$-th periodic income, $\mathrm{I}_{\mathrm{wd}, \mathrm{i}}$ - the amount of income achieved during the decommission phase, $\mathrm{n}_{\mathrm{AI}, \mathrm{i}}, \mathrm{n}_{\mathrm{NAI}, \mathrm{i}}$ - the respective number (multiplicity) of operational incomes of an annual and periodic nature, $\mathrm{PWF}_{\mathrm{AI}, \mathrm{i}}-$ the value of the discount factor for annual incomes, $\mathrm{PWF}_{\mathrm{NAI}, \mathrm{im}}-$ the value of the discount factor for the $\mathrm{m}$-th periodic income, $\mathrm{PWF}_{\mathrm{WD}, \mathrm{i}}$ - the value of the discount factor for income achieved in the decommission phase; the overline in the formula means that the given value is a fuzzy number. 
The amount of the LCEAC criterion is the product of LCC and the AF factor (annual discount factor - annuity factor). The cost addition for risk $\left(\Delta \mathrm{R}_{\mathrm{LCC}}\right)$ criterion is calculated as the difference between the amount of life cycle costs of a building, which takes into account the impact of risk (LCC), and the value of life cycle costs of a building, which does not include this impact (LCC ${ }^{\mathrm{REF}}$ ). Both amounts mentioned here (LCC, LCC ${ }^{\mathrm{REF}}$ ) are calculated with equation (1.1).

The input data for the model estimating the whole life costs of buildings that allows the quantification of the cost addition for risk are divided into the following parameters:

- temporal CG (of a global character), that is, the duration of the life cycle of the building $\mathrm{T}_{\mathrm{i}}$, where $T_{i}$ equals the estimated service life of a building (ESLB),

- temporal CL (of a local character), that is, times $t_{i k}, t_{i m}$, after which the $k$-th periodic operating cost or $\mathrm{m}$-th periodic income is calculated accordingly,

- financial FG (of a global character), in the form of a discount rate (r), which is necessary to calculate the net present value of a given monetary amount based on its value determined in future time,

- financial FK (understood as costs that may occur in the life cycle of a building), among which the annual costs are distinguished - annual operating costs $\mathrm{C}_{\mathrm{opA}, \mathrm{ij}}$ and periodic consecutively, initial costs $C_{\mathrm{in}, \mathrm{i}}$, periodic operating costs $\mathrm{C}_{\mathrm{opNA}}$,ik and decommission costs $\mathrm{C}_{\mathrm{wd}, \mathrm{i}}$,

- financial FP (understood as revenues that may occur in the life cycle of a building), namely incomes of annual character - annual $\mathrm{I}_{\mathrm{opA}, \mathrm{il}}$ and periodic - consecutively, periodic incomes obtained during the building operation phase $\mathrm{I}_{\mathrm{opNA}}$,im and the incomes obtained during the decommission phase $I_{w d, i}$.

To parameterize the above-mentioned input data in the model for estimating the whole life costs of buildings convex and normal fuzzy numbers were used. Fig. 1 presents the basic set of membership functions of fuzzy numbers (functions with piecewise linear charts) for input data not affected by risk (Fig. 1.a), discount rate (Fig. 1.b) and time parameters CG and CL, as well as financial FG and FL in the case when the impact of risk on the amount of a given parameter is taken into account (Fig. 1.c and Fig. 1.d). 

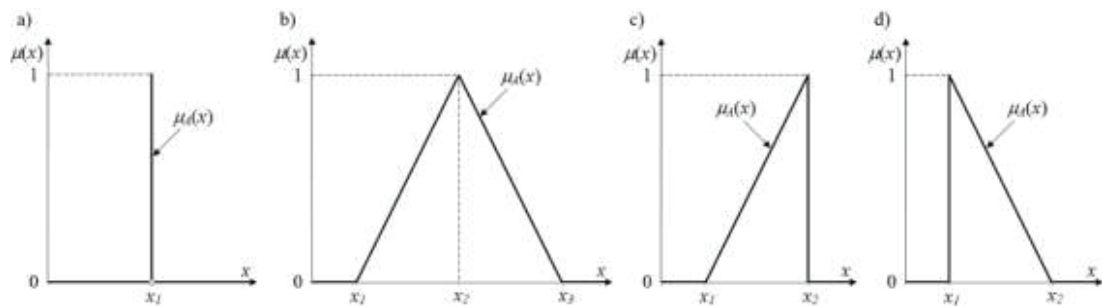

Fig. 1. Membership functions of fuzzy numbers for input parameters - basic set

\section{VERIFICATION STUDIES AND SENSITIVITY ANALYSIS OF THE MODEL}

\subsection{CAlCulation EXAMPLE (LifE CYCLE COSTS ANALYSIS - LCCA)}

The calculation example concerns the comparison of three alternative solutions of a multi-family building, which result from the need to take into account the impact of the identified risk factors in its life cycle. This example is also the basis for further verification tests and sensitivity analyses.

An economic life cycle analysis (LCCA) was performed for the investor (a Cracow housing cooperative) taking into account all the comparative criteria covered by the model's operation. Both the example and the results are discussed in detail in doctoral thesis [18].

After conducting an assessment of the impact of identified risk factors $Z_{1}$ ("errors in designs") and $\mathrm{Z}_{2}$ ("incorrect assumptions for construction and material solutions") on the amount of the corresponding life cycle cost components of the building, life cycle scenarios have been defined for all alternative building solutions including the need for adoption of the way of reacting to identified and assessed risk factors and building management strategies during the operation phase due to the types of maintenance in accordance with the assumptions of the ISO standard 15686-5:2008 [7].

In three scenarios of the building's life cycle, the following three types of maintenance were proposed: prevention of structural deterioration (preventive maintenance in scenario $i=1$ ), repairoriented maintenance (corrective maintenance in scenario $\mathrm{i}=2$ ) and maintenance postponed until repairs are made, but only when the repair should be classified as urgent, that is, one that can have significant consequences for the life cycle cost of the building (deferred maintenance in scenario $i=$ 3). Moreover, scenarios $i=1$ and $i=2$ assume that total sale of residential space will take place in the first five years of building operation, and annual revenues will be those obtained from rents for 
housing space and for renting service areas. In scenario $i=3$ the assumption of a long-term rental of the living space (with a constant rent indicator at the level of $85 \%$ ) was adopted.

Table 1 presents the parameter values adopted for the LCCA analysis for each defined life cycle scenario of an alternative building solution. Fig. 2 illustrates an exemplary graph of results obtained for the economic criterion of life cycle costs (LCC).

Table 1. Data accepted for LCCA analysis

\begin{tabular}{|c|c|c|c|c|c|}
\hline \multicolumn{2}{|l|}{ Parameters } & Scenario $\mathrm{i}=0$ & Scenario $\mathrm{i}=1$ & Scenario $i=2$ & Scenario $\mathrm{i}=3$ \\
\hline \multicolumn{2}{|c|}{$\begin{array}{l}\text { Life cycle duration } \\
\qquad\left(\mathrm{T}_{\mathrm{i}}=\mathrm{ESLB}\right)\end{array}$} & $50 \mathrm{yrs}$. & $50 \mathrm{yrs}$. & $\begin{array}{l}\text { no more than } 60 \\
\text { yrs. ( } \Gamma \text { class m.f., } \\
\text { Fig. } 1 . c)\end{array}$ & 50 yrs. \\
\hline \multicolumn{2}{|c|}{ Discount rate $(\mathrm{r})$} & \multicolumn{4}{|c|}{ about $8 \%$ (triangular m.f., Fig. 1.b) } \\
\hline \multicolumn{2}{|c|}{ Initial costs $\left(\mathrm{C}_{\mathrm{in}, \mathrm{i}}\right)$} & 7206100 PLN & $\begin{array}{l}\text { no more than } \\
7427400 \text { PLN } \\
\text { ( } \Gamma \text { class m.f., } \\
\text { Fig. } 1 . c)\end{array}$ & $\begin{array}{c}\text { no more than } \\
7333700 \text { PLN } \\
\text { ( } \Gamma \text { class m.f., } \\
\text { Fig. } 1 . c \text { ) }\end{array}$ & 7206100 PLN \\
\hline \multicolumn{2}{|c|}{$\begin{array}{l}\text { Annual operating costs } \\
\left(\mathrm{C}_{\mathrm{opA}, \mathrm{ij}}\right)\end{array}$} & 101400 PLN & 101400 PLN & 103800 PLN & 99000 PLN \\
\hline \multirow{5}{*}{$\begin{array}{c}\text { Periodic } \\
\text { operating costs } \\
\left(\mathrm{C}_{\mathrm{opNA}, \mathrm{ik}}\right) \\
\text { after the time of } \\
\quad\left(\mathrm{t}_{\mathrm{ik}}\right)=\ldots\end{array}$} & 10 & 227400 PLN & 227400 PLN & 272500 PLN & 182300 PLN \\
\hline & 20 & 227400 PLN & $227400 \mathrm{PLN}$ & $272500 \mathrm{PLN}$ & $182300 \mathrm{PLN}$ \\
\hline & 30 & 909700 PLN & 909700 PLN & $\begin{array}{l}\text { no more than } \\
1090000 \text { PLN } \\
\text { ( } \Gamma \text { class m.f., } \\
\text { Fig. } 1 . c)\end{array}$ & 182300 PLN \\
\hline & 40 & 227400 PLN & 227400 PLN & 272500 PLN & $\begin{array}{l}\text { no more than } \\
1270300 \text { PLN } \\
\text { ( } \Gamma \text { class m.f., } \\
\text { Fig. } 1 . c) \\
\end{array}$ \\
\hline & 50 & not applicable & not applicable & 272500 PLN & not applicable \\
\hline \multicolumn{2}{|c|}{$\begin{array}{c}\text { Decommission costs } \\
\left(\mathrm{C}_{\mathrm{wd}, \mathrm{i}}\right) \text { after }\left(\mathrm{T}_{\mathrm{i}}=\mathrm{ESLB}\right)\end{array}$} & 521400 PLN & 547500 PLN & 547500 PLN & 0 PLN \\
\hline \multirow{4}{*}{$\begin{array}{l}\text { Annual incomes } \\
\left(\mathrm{I}_{\mathrm{opA}, \mathrm{il}}\right) \text { to and after } \\
\text { the time of } \\
\left(\mathrm{t}_{\mathrm{im}}\right)=\ldots \\
\text { (rents) }\end{array}$} & \multirow{2}{*}{30} & not applicable & 201800 PLN & 208600 PLN & not applicable \\
\hline & & not applicable & 208600 PLN & 215400 PLN & not applicable \\
\hline & \multirow{2}{*}{40} & not applicable & not applicable & not applicable & 1037400 PLN \\
\hline & & not applicable & not applicable & not applicable & 1070100 PLN \\
\hline \multirow{5}{*}{$\begin{array}{c}\text { Periodic } \\
\text { operational } \\
\text { incomes }\left(\mathrm{I}_{\mathrm{opNA}, \mathrm{im}}\right) \\
\text { after the time of } \\
\left(\mathrm{t}_{\mathrm{im}}\right)=\ldots \\
\text { (sale of flats) }\end{array}$} & 1 & not applicable & 8000300 PLN & 7899500 PLN & not applicable \\
\hline & 2 & not applicable & 2461600 PLN & 2430600 PLN & not applicable \\
\hline & 3 & not applicable & 1230800 PLN & 1215300 PLN & not applicable \\
\hline & 4 & not applicable & 492300 PLN & 486100 PLN & not applicable \\
\hline & 5 & not applicable & 123000 PLN & 121500 PLN & not applicable \\
\hline \multicolumn{2}{|c|}{$\begin{array}{l}\text { Incomes }\left(\mathrm{I}_{\mathrm{wd}, \mathrm{i}}\right) \\
\text { from the sale of the plot } \\
\text { over time (ESLB) }\end{array}$} & not applicable & 1940000 PLN & 1940000 PLN & not applicable \\
\hline \multicolumn{2}{|c|}{$\begin{array}{l}\text { Incomes }\left(\mathrm{I}_{\mathrm{wd}, \mathrm{i}}\right) \text { from } \\
\text { the sale of the plot with } \\
\text { the building over time } \\
\text { (ESLB) }\end{array}$} & not applicable & not applicable & not applicable & 10297000 PLN \\
\hline
\end{tabular}




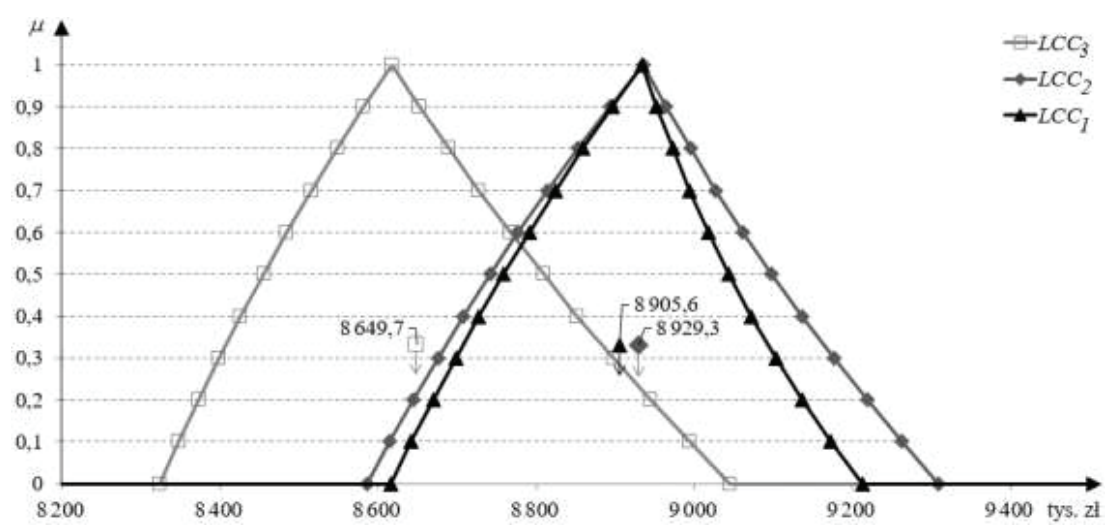

Fig. 2. Resulting distributions of membership for the LCC criterion - basic set

The LCCA analysis revealed that:

- the lowest (most favourable) value of the LCC is ensured by the implementation of scenario $\mathrm{i}=3\left(\mathrm{LCC}_{3}=8649700 \mathrm{PLN}\right)$, and the highest by scenario $\mathrm{i}=2\left(\mathrm{LCC}_{2}=8929300 \mathrm{PLN}\right)$,

- the lowest (most favourable) value of LCEAC is obtained for scenario $\mathrm{i}=3\left(\mathrm{LCEAC}_{3}=716\right.$ 900 PLN), and the highest for scenario $i=1\left(\mathrm{LCEAC}_{1}=737300 \mathrm{PLN}\right)$,

- the highest (most favourable) value of WLC is generated by the implementation of scenario $\mathrm{i}=1\left(\mathrm{WLC}_{1}=4611700 \mathrm{PLN}\right)$, and the lowest by scenario $\mathrm{i}=2\left(\mathrm{WLC}_{2}=4540400 \mathrm{PLN}\right)$,

- the lowest (most favourable) value of $\Delta \mathrm{R}_{\mathrm{LCC}}$ is achieved by the implementation of scenario $\mathrm{i}$ $=3\left(\Delta \mathrm{R}_{\mathrm{LCC}, 3}=-107900 \mathrm{PLN}\right)$, and the highest by scenario $\mathrm{i}=2\left(\Delta \mathrm{R}_{\mathrm{LCC}, 2}=171700 \mathrm{PLN}\right)$.

In addition, it can be emphasized that in the case of scenario $i=3$, there may be circumstances in the life cycle of the building that, due to the risk involved, will not burden the investor with additional costs (a loss, when $\Delta \mathrm{R}_{\mathrm{LCC}}$ is greater than 0 ), but instead they will create an over-profit (benefit, when $\Delta \mathrm{R}_{\mathrm{LCC}}$ is lower than 0 ).

\subsection{MODEL VERIFICATION BY MEANS OF LIFE CYCLE NET PRESENT VALUE}

The model of estimating the whole life costs of the building enabling the quantification of the risk addition was checked by means of a deterministic method, life cycle net present value (LCNPV), the generalized formula of which has the following form (3.1). 


$$
L C N P V=\sum_{i=0}^{n} \frac{C F_{i}}{(1+r)^{i}}
$$

where:

$\mathrm{CF}_{\mathrm{i}}$ - cash flow in i-th year, $\mathrm{n}$ - number of years in the life cycle, $\mathrm{i}$ - subsequent year, $\mathrm{r}$ - discount rate.

The tests were performed in terms of the convergence of results generated by the model of estimating the whole life costs of the building with the results obtained by the LCNPV method. The following assumptions were adopted:

- calculating the amount of the economic comparison criteria LCC, LCEAC, WLC and $\triangle \mathrm{R}_{\mathrm{LCC}}$ for the reference scenario and all the i-th building life cycle scenarios, which are presented in the calculation example (chapter 3.1),

- modelling time and financial input data as certain values (not affected by risk),

- applying singleton membership functions in the estimation model of the building whole life costs (Fig. 1.a), both for temporal and financial data,

- accepting a fixed value of the discount rate $(r=8 \%)$,

- adopting maximum values for financial data according to Table 1.

The results of the simulation are presented in Table 2 .

Table 2. Results of the verification of the model for estimating the total cost of the building life using the

\section{LCNPV method}

\begin{tabular}{|c|c|c|c|c|}
\hline $\begin{array}{l}\text { Comparative } \\
\text { criterion }\end{array}$ & $\begin{array}{l}\text { Model for estimating the } \\
\text { whole life costs of buildings }\end{array}$ & LCNPV method & \multicolumn{2}{|c|}{ Differences } \\
\hline \multirow{4}{*}{ LCC } & $\mathrm{LCC}_{0}=8712682 \mathrm{PLN}$ & $\mathrm{LCC}_{0}=8712682 \mathrm{PLN}$ & $0 \mathrm{PLN}$ & $0 \%$ \\
\hline & $\mathrm{LCC}_{1}=8934538 \mathrm{PLN}$ & $\mathrm{LCC}_{1}=8934538 \mathrm{PLN}$ & 0 PLN & $0 \%$ \\
\hline & $\mathrm{LCC}_{2}=8935152 \mathrm{PLN}$ & $\mathrm{LCC}_{2}=8935152 \mathrm{PLN}$ & 0 PLN & $0 \%$ \\
\hline & $\mathrm{LCC}_{3}=8617357$ PLN & $\mathrm{LCC}_{3}=8617357 \mathrm{PLN}$ & 0 PLN & $0 \%$ \\
\hline \multirow{3}{*}{ LCEAC } & LCEAC $_{1}=730335$ PLN & LCEAC $_{1}=730335$ PLN & $0 \mathrm{PLN}$ & $0 \%$ \\
\hline & LCEAC $_{2}=721942$ PLN & LCEAC $_{2}=721942$ PLN & 0 PLN & $0 \%$ \\
\hline & LCEAC $_{3}=704407$ PLN & LCEAC $_{3}=704407$ PLN & 0 PLN & $0 \%$ \\
\hline \multirow{3}{*}{ WLC } & $\mathrm{WLC}_{1}=4522903$ PLN & $\mathrm{WLC}_{1}=4522903$ PLN & $0 \mathrm{PLN}$ & $0 \%$ \\
\hline & $\mathrm{WLC}_{2}=4476296 \mathrm{PLN}$ & $\mathrm{WLC}_{2}=4476296 \mathrm{PLN}$ & 0 PLN & $0 \%$ \\
\hline & $\mathrm{WLC}_{3}=4303305 \mathrm{PLN}$ & $\mathrm{WLC}_{3}=4303305$ PLN & 0 PLN & $0 \%$ \\
\hline \multirow{3}{*}{$\Delta \mathrm{R}_{\mathrm{LCC}}$} & $\Delta \mathrm{R}_{\mathrm{LCC}, 1}=221856 \mathrm{PLN}$ & $\Delta \mathrm{R}_{\mathrm{LCC}, 1}=221856 \mathrm{PLN}$ & 0 PLN & $0 \%$ \\
\hline & $\Delta \mathrm{R}_{\mathrm{LCC}, 2}=222471 \mathrm{PLN}$ & $\Delta \mathrm{R}_{\mathrm{LCC}, 2}=222471 \mathrm{PLN}$ & 0 PLN & $0 \%$ \\
\hline & $\Delta \mathrm{R}_{\mathrm{LCC}, 3}=-95325 \mathrm{PLN}$ & $\Delta \mathrm{R}_{\mathrm{LCC}, 3}=-95325 \mathrm{PLN}$ & 0 PLN & $0 \%$ \\
\hline
\end{tabular}




\subsection{INVESTIGATION ON THE EFFECT OF CHANGING THE VALUES OF TEMPORAL AND FINANCIAL DATA ON CALCULATION RESULTS}

For the purpose of studying the impact of changes in the values of temporal and financial input data on the results of calculations generated by the model for estimating the whole life costs of the building that allows the quantification of the risk addition the ISO 15686-5:2008 standard proposal was used [7] and the results for economic comparative criteria were simulated (LCC, LCEAC, WLC and $\Delta \mathrm{R}_{\mathrm{LCC}}$ ) for a selected scenario of the life cycle of an alternative building solution from the example shown in chapter 3.1. The following scope of changes was adopted related to the parameterization of temporal and financial data in relation to the data originally accepted for the LCCA analysis for scenario $i=2$ :

- the value of discount rate (r) - change by $\pm 1 \%$ (from about $8 \%$ to about $7 \%$ and about $9 \%$ ),

- life cycle duration $\left(\mathrm{T}_{2}\right)$ - change by \pm 5 years (from no more than 60 years to no more than 55 years and no more than 65 years),

- the amount of initial costs $\left(\mathrm{C}_{\mathrm{in}, 2}\right)$ - change by $\pm 10 \%$ (from no more than PLN 7333700 to no more than PLN 6600330 and no more than PLN 8067 070),

- the amount of operation costs $\left(\mathrm{C}_{\mathrm{opNA}, 230}\right)$ - change by $\pm 10 \%$ (from no more than 1090000 PLN to no more than 981000 PLN and no more than 1199000 PLN),

while it is assumed that the results will be generated only for the basic set of the membership function using the centre of gravity method $(\mathrm{CoG})$ to defuzzification the resulting value.

Table 3 presents the results of the simulation of the impact of changing the value of input data on the calculation results. It should be noted that the changes in the value of temporal and financial data for the life cycle duration, the discount rate, initial costs and operating costs, were made assuming that combinations of changes of many parameters will not be taken into account. Thus, 8 combinations were considered, which are specified in Table 3.

Table 3. Results of the simulation of the impact of changing the value of temporal and financial input data on the calculation results

\begin{tabular}{|c|c|c|c|c|c|c|c|c|c|}
\hline \multirow{3}{*}{ Parameters } & \multirow{3}{*}{ Mod. } & \multicolumn{8}{|c|}{ Result values for comparative criteria } \\
\hline & & \multicolumn{2}{|c|}{$\mathrm{LCC}_{2}$} & \multicolumn{2}{|c|}{ LCEAC $_{2}$} & \multicolumn{2}{|c|}{$\mathrm{WLC}_{2}$} & \multicolumn{2}{|c|}{$\Delta \mathrm{R}_{\mathrm{ICC} 2}$} \\
\hline & & PLN & $\%$ & PLN & $\%$ & PLN & $\%$ & PLN & $\%$ \\
\hline $\begin{array}{l}\text { Reference values } \\
(\text { scenario } \mathrm{i}=2)\end{array}$ & $\begin{array}{l}\text { not } \\
\text { appl. }\end{array}$ & 8935152 & $\begin{array}{l}\text { not } \\
\text { appl. }\end{array}$ & 735000 & $\begin{array}{l}\text { not } \\
\text { appl. }\end{array}$ & 4540400 & $\begin{array}{l}\text { not } \\
\text { appl. }\end{array}$ & 171700 & $\begin{array}{l}\text { not } \\
\text { appl. }\end{array}$ \\
\hline \multirow{2}{*}{$\begin{array}{l}\text { Life cycle duration } \\
\left(\mathrm{T}_{2}\right)\end{array}$} & $-5 \mathrm{yr}$. & 8921900 & $-0,08 \%$ & 741200 & $+0,84 \%$ & 4545200 & $+0,11 \%$ & 174000 & $+1,34 \%$ \\
\hline & $+5 \mathrm{yr}$. & 8934700 & $+0,06 \%$ & 730700 & $-0,59 \%$ & 4536900 & $-0,08 \%$ & 170200 & $-0,87 \%$ \\
\hline \multirow{2}{*}{ Discount rate $(r)$} & $-1 \%$ & 9185800 & $+2,87 \%$ & 799300 & $+8,75 \%$ & 4821300 & $+6,19 \%$ & 193000 & $+12,41 \%$ \\
\hline & $+1 \%$ & 8727400 & $-2,26 \%$ & 674500 & $-8,23 \%$ & 4291800 & $-5,48 \%$ & 156600 & $-8,79 \%$ \\
\hline
\end{tabular}




\begin{tabular}{|c|c|c|c|c|c|c|c|c|c|}
\hline \multirow{2}{*}{ Initial costs $\left(\mathrm{C}_{\mathrm{in}, 2}\right)$} & $-10 \%$ & 8200200 & $-8,17 \%$ & 675400 & $-8,11 \%$ & 5269500 & $+16,06 \%$ & 163200 & $-4,95 \%$ \\
\cline { 2 - 10 } & $+10 \%$ & 9658400 & $+8,17 \%$ & 794700 & $+8,12 \%$ & 3811300 & $-16,06 \%$ & 180200 & $+4,95 \%$ \\
\hline $\begin{array}{c}\text { Operation costs } \\
\left(\mathrm{C}_{\mathrm{opNA}, 230}\right)\end{array}$ & $-10 \%$ & 8918500 & $-0,12 \%$ & 734100 & $-0,12 \%$ & 4551300 & $+0,24 \%$ & 170700 & $-0,58 \%$ \\
\cline { 2 - 10 } & $+10 \%$ & 8940100 & $+0,12 \%$ & 736000 & $+0,14 \%$ & 4529600 & $-0,24 \%$ & 172700 & $+0,58 \%$ \\
\hline
\end{tabular}

As the analysis of the results reveal, the model of estimating the whole life costs of the building enabling the quantification of the cost addition for risk generated the size of the LCC, LCEAC, WLC and $\Delta \mathrm{R}_{\mathrm{LCC}}$ comparison criteria for a selected building life cycle scenario $(\mathrm{i}=2)$, which differ from the values obtained for reference values.

By changing the value of each input, the following results were obtained, according to which:

- shortening the life cycle duration $\left(\mathrm{T}_{2}\right)$ by 5 years does not have a significant impact on the life cycle costs of the building ( $\mathrm{LCC}_{2}$ - reduction by $0,08 \%$ ), the life cycle equivalent annual cost of the building $\left(\mathrm{LCEAC}_{2}\right.$ - increase by $\left.0,84 \%\right)$ and the whole life costs $\left(\mathrm{WLC}_{2}-\right.$ increase by $0,11 \%)$; also in the case of the cost addition for risk $\left(\Delta \mathrm{R}_{\mathrm{LCC}, 2}\right)$, the increase in its value by $1,34 \%$ can be considered insignificant,

- lengthening the life cycle duration $\left(T_{2}\right)$ by 5 years does not have a significant impact on the value of $\mathrm{LCC}_{2}$ (increase by $0,06 \%$ ), $\mathrm{LCEAC}_{2}$ (reduction by $0,59 \%$ ) and $\mathrm{WLC}_{2}$ (reduction by $0,08 \%$ ); also in the case of the $\Delta \mathrm{R}_{\mathrm{LCC}, 2}$ criterion, the reduction of its value by $0,87 \%$ can be considered insignificant,

- reduction of the discount rate (r) by $1 \%$ does not have a significant impact on the value of $\mathrm{LCC}_{2}$ (increase by 2,87\%); in the case of the criteria $\mathrm{LCEAC}_{2}$ (increase by $8,75 \%$ ), $\mathrm{WLC}_{2}$ (increase by $6,19 \%$ ) or $\Delta \mathrm{R}_{\mathrm{LCC}}, 2$ (increase by $12,41 \%$ ), it should be concluded that the criteria listed here will be more sensitive if the discount rate changes more than $\pm 1 \%$,

- increase of the discount rate (r) by $1 \%$ does not have a significant impact on the value of $\mathrm{LCC}_{2}$ (reduction by $2,26 \%$ ); in the case of the criteria $\mathrm{LCEAC}_{2}$ (reduction by $8,23 \%$ ), $\mathrm{WLC}_{2}$ (reduction by $5,48 \%$ ) and $\Delta \mathrm{R}_{\mathrm{LCC}, 2}$ (reduction by $8,79 \%$ ), it should be concluded that the criteria listed here will be more sensitive if the discount rate changes more than $\pm 1 \%$,

- reduction of initial costs $\left(\mathrm{C}_{\mathrm{in}, 2}\right)$ by $10 \%$ causes a reduction in the value of $\mathrm{LCC}_{2}$ by $8,17 \%$, $\mathrm{LCEAC}_{2}$ by $8,11 \%$ and $\Delta \mathrm{R}_{\mathrm{LCC}, 2}$ by $4,95 \%$; in the case of the $\mathrm{WLC}_{2}$ criterion, its value increases by $16,06 \%$; it should be concluded that all of the criteria listed here will be more sensitive if the value of initial costs changes to one greater than $\pm 10 \%$,

- increase of initial costs $\left(\mathrm{C}_{\mathrm{in}, 2}\right)$ by $10 \%$ causes an increase in the value $\mathrm{LCC}_{2}$ by $8,17 \%$, LCEAC 2 by $8,12 \%$ and $\Delta \mathrm{R}_{\mathrm{LCC}, 2}$ by $4,95 \%$; in the case of the $\mathrm{WLC}_{2}$ criterion, its value decreases by $16,06 \%$; it should be concluded that all of the criteria listed here will be more sensitive if the value of initial costs changes to one greater than $\pm 10 \%$, 
- reduction of operation costs $\left(\mathrm{C}_{\mathrm{opNA}, 230}\right)$ by $10 \%$ causes a reduction in the value of $\mathrm{LCC}_{2}$ by $0,12 \%, \operatorname{LCEAC}_{2}$ by $0,12 \%$ and $\Delta \mathrm{R}_{\mathrm{LCC}, 2}$ by $0,58 \%$; in the case of the $\mathrm{WLC}_{2}$ criterion, its value increases by $0,24 \%$; it should be concluded that all of the criteria listed here do not have a significant impact on the change in the resulting values,

- increase of operation costs $\left(\mathrm{C}_{\mathrm{opNA}, 230}\right)$ by $10 \%$ causes an increase in the value $\mathrm{LCC}_{2}$ by $0,12 \%, \mathrm{LCEAC}_{2}$ by $0,14 \%$ and $\Delta \mathrm{R}_{\mathrm{LCC}, 2}$ by $0,58 \%$; in the case of the $\mathrm{WLC}_{2}$ criterion, its value decreases by $0,24 \%$; it should be concluded that all of the criteria listed here do not have a significant impact on the change in the resulting values.

\subsection{INVESTIGATION OF THE SENSITIVITY OF THE MODEL ON THE POSSIBILITY OF CHANGING PARAMETERS AFFECTING CALCULATION RESULTS}

For temporal and financial data which in the calculation example (chapter 3.1) were modelled as uncertain values, the basic set of membership functions was changed to other alternative function sets:

- alternative I, which includes piecewise square functions,

- alternative II, created by harmonic functions,

- alternative III, made of the most complex Gaussian membership functions.

It was also assumed that the results should be verified by two defuzzification methods, that is, the centre of gravity method ( $\mathrm{CoG}$ - the basic method) or the area compensation method (AC - the alternative method).

In the case of the parameterization of temporal and financial data for the alternative set of membership functions no. III (the Gaussian functions), the width of the curve distribution $\sigma$ for fuzzy numbers was chosen in such a way that the degrees of membership $\mu(\mathrm{x})$ in $\alpha$-cuts $0 ; 0,5$ and 1 were equal or close to these values.

For each of the 84 combinations ( 8 cases for each comparative criterion LCC, LCEAC and WLC for the scenarios of building life cycle from $i=1$ to $i=3$ and 4 cases for the $\Delta R_{L C C}$ criterion), sharp results were calculated. The results obtained were tabulated with the following values: arithmetic average (m), standard deviation (s) and coefficient of variation $(\mathrm{V})$, which was calculated by means of equation (3.2).

$$
V=\frac{s}{|m|}
$$


where:

$\mathrm{m}-$ arithmetic average, $\mathrm{s}-$ standard deviation.

Table 4 and table 5 reveal the results obtained for all cases of 84 combinations of membership function sets and methods for defuzzification the resulting value for the economic comparison criteria (LCC, LCEAC, WLC and $\Delta \mathrm{R}_{\mathrm{LCC}}$ ). Table 5 also marks that in the case of the $\Delta \mathrm{R}_{\mathrm{LCC}}$ the area compensation method (AC) is not possible to be applied to defuzzification the result, because part of the resulting values in the individual $\alpha$-cuts assume negative values, which disqualifies this method.

Table 4. Result values for the LCC and LCEAC criteria depending on the choice of the set of membership functions and the method of defuzzification

\begin{tabular}{|c|c|c|c|c|c|c|c|c|}
\hline \multicolumn{2}{|c|}{ Comparative criterion } & \multicolumn{3}{c|}{ LCC } & \multicolumn{3}{c|}{ LCEAC } \\
\hline \multicolumn{2}{|c|}{$\begin{array}{c}\text { Scenario of building's life cycle } \\
\text { functions }\end{array}$} & $\begin{array}{c}\text { Defuzzific. } \\
\text { method }\end{array}$ & PLN & PLN & PLN & PLN & PLN & PLN \\
\hline 1 & Basic & CoG & 8905600 & 8929300 & 8649700 & 737300 & 735000 & 716900 \\
\hline 2 & Basic & AC & 8909100 & 8927200 & 8638400 & 734400 & 730300 & 712600 \\
\hline 3 & Alternative I & CoG & 8903700 & 8925000 & 8641600 & 734800 & 731500 & 713900 \\
\hline 4 & Alternative I & AC & 8905500 & 8923700 & 8635550 & 733300 & 728900 & 711600 \\
\hline 5 & Alternative II & CoG & 8903900 & 8925600 & 8642600 & 735200 & 732000 & 714300 \\
\hline 6 & Alternative II & AC & 8906400 & 8924200 & 8635900 & 733400 & 729100 & 711700 \\
\hline 7 & Alternative III & CoG & 8908000 & 8931400 & 8652100 & 738300 & 736600 & 718700 \\
\hline 8 & Alternative III & AC & 8908000 & 8927000 & 8640100 & 735000 & 731200 & 713700 \\
\hline & Arithmetic average & $\mathrm{m}$ & 8906275 & 8926675 & 8641994 & 735213 & 731825 & 714175 \\
\hline & Standard deviation & $\mathrm{s}$ & 698 & 931 & 2143 & 1761 & 2718 & 2492 \\
\hline Coefficient of variation & $\mathrm{V}$ & $0,01 \%$ & $0,01 \%$ & $0,02 \%$ & $0,24 \%$ & $0,37 \%$ & $0,35 \%$ \\
\hline
\end{tabular}

Table 5. Result values for the WLC and $\Delta \mathrm{R}_{\mathrm{LCC}}$ criteria depending on the choice of the set of membership functions and the method of defuzzification

\begin{tabular}{|c|c|c|c|c|c|c|c|c|}
\hline \multicolumn{3}{|c|}{ Comparative criterion } & \multicolumn{3}{c|}{ WLC } & \multicolumn{3}{c|}{$\Delta \mathrm{R}_{\mathrm{LCC}}$} \\
\hline & $\begin{array}{c}\text { Scenario of building's life cycle } \\
\text { Set of membership } \\
\text { functions }\end{array}$ & $\begin{array}{c}\text { Defuzzific. } \\
\text { method }\end{array}$ & $\mathrm{i}=1$ & $\mathrm{i}=2$ & $\mathrm{i}=3$ & $\mathrm{i}=1$ & $\mathrm{i}=2$ & $\mathrm{i}=3$ \\
\hline 1 & Basic & $\mathrm{CoG}$ & 4611700 & 4540400 & 4543800 & 147800 & 171700 & -107900 \\
\hline 2 & Basic & $\mathrm{AC}$ & 4582200 & 4517300 & 4428150 & not applic. & not applic. & not applic. \\
\hline 3 & Alternative I & $\mathrm{CoG}$ & 4594800 & 4526500 & 4457300 & 156800 & 178100 & -105400 \\
\hline 4 & Alternative I & $\mathrm{AC}$ & 4579950 & 4514850 & 4398750 & not applic. & not applic. & not applic. \\
\hline 5 & Alternative II & $\mathrm{CoG}$ & 4597200 & 4528600 & 4469800 & 155500 & 177300 & -105800 \\
\hline 6 & Alternative II & $\mathrm{AC}$ & 4580350 & 4515300 & 4403050 & not applic. & not applic. & not applic. \\
\hline 7 & Alternative III & $\mathrm{CoG}$ & 4613200 & 4544500 & 4549800 & 146500 & 173100 & -111300 \\
\hline 8 & Alternative III & $\mathrm{AC}$ & 4586800 & 4521900 & 4438300 & not applic. & not applic. & not applic. \\
\hline & Arithmetic average & $\mathrm{m}$ & 4593275 & 4526169 & 4461119 & 151650 & 175050 & -107600 \\
\hline & Standard deviation & $\mathrm{s}$ & 13435 & 11261 & 58138 & 2625 & 1565 & 1350 \\
\hline \multicolumn{2}{|c|}{ Coefficient of variation } & $\mathrm{V}$ & $0,29 \%$ & $0,25 \%$ & $1,30 \%$ & $1,73 \%$ & $0,89 \%$ & $1,25 \%$ \\
\hline
\end{tabular}


The analysis of the coefficients of variation $\mathrm{V}$ value reveals that:

- the average value of the coefficient of variation $\mathrm{V}$ for all cases investigated is $\mathrm{V}_{\mathrm{m}}=0,58 \%$,

- maximum value of the coefficient of variation $\mathrm{V}_{\max }=1,73 \%$ was obtained only in 1 out of 12 analysed cases, which constitutes approximately $8,33 \%$ of all examined cases,

- in 8 out of all 12 cases $(66,67 \%$ of all examined cases), coefficient of variation $\mathrm{V}$ values were lower than the average value $\mathrm{V}_{\mathrm{m}}=0,58 \%$,

- in 9 out of all 12 cases $(75,00 \%$ of all examined cases), coefficient of variation $\mathrm{V}$ values were lower than $1 \%$,

- in the case of the building life cycle cost criterion (LCC), coefficient of variation $\mathrm{V}$ values were only $0,01 \%$ and $0,02 \%$ (for the building life cycle scenarios $i=1, i=2$ and $i=3$, respectively),

- in none of the cases the coefficient of variation $\mathrm{V}$ value exceeded $10 \%$.

\section{CONCLUSIONS}

Based on the description of the verification study and sensitivity analyses performed in this paper, it can be concluded that the model for estimating the whole life costs of buildings enabling the quantification of the risk addition generates fully convergent output values of LCC, LCEAC, WLC and $\Delta \mathrm{R}_{\mathrm{LCC}}$ comparative criteria for all life cycle scenarios with the results obtained by calculations of the life cycle net present value deterministic method (LCNPV). This is illustrated by the test results described in chapter 3.2 and presented in table 2 .

Testing the sensitivity of the model to the possible change in the value of temporal and financial input data to the results of calculations (chapter 3.3) indicated financial parameters (discount rate $-r$ and initial costs $-C_{\text {in }}$ ) that if the value changes within a range exceeding $\pm 1 \%$ for ( $r$ ) and $\pm 10 \%$ for $\left(\mathrm{C}_{\text {in }}\right)$ respectively, they will increasingly influence the value of results for all economic criteria.

In the case of testing the sensitivity of the model to the possibility of changes in the parameters affecting the results of calculations (change of the set of membership functions and the method of defuzzification the result), the maximum value of the coefficient of variation was $V_{\max }=1,73 \%$ for one of the investigated cases. Thus, in none of the analysed cases the value of $\mathrm{V}$ exceeded $10 \%$, which is mentioned by Zeliaś and Pawełek [20]. Basing on the results obtained and described in chapter 3.4 (table 4 and table 5), it was found that all parameters that may affect the results indicate insignificant differentiation of the resulting values for economic comparative criteria (LCC, LCEAC, WLC and $\triangle \mathrm{R}_{\mathrm{LCC}}$ ). The study of the sensitivity of the model for estimating the whole life costs of the buildings, therefore, confirms the very high homogeneity of the obtained results. 


\section{REFERENCES}

1. M. Apollo, A. Siemaszko, E. Miszewska-Urbańska, "The selected roof covering technologies in the aspect of their life cycle costs", Open Engineering 8(1): 478-483, 2018.

2. L. F., Cabeza, L. Rincón, V. Vilariño, G. Pérez, A. Castell, "Life cycle assessment (LCA) and life cycle energy analysis (LCEA) of buildings and the building sector: A review", Renewable and sustainable energy reviews 29: 394-416, 2014.

3. E. Di Giuseppe, M. Iannaccone, M. Telloni, M. D’Orazio, C. Di Perna, "Probabilistic life cycle costing of existing buildings retrofit interventions towards nZE target: Methodology and application example", Energy and Buildings 144: 416-432, 2017.

4. B. Grzyl, M. Apollo, E. Miszewska-Urbańska, A. Kristowski, „Zarządzanie eksploatacją obiektu w ujęciu kosztów cyklu życia", Acta Scientiarum Polonorum. Seria: Architectura 16(2): 85-89, 2017.

5. I. Hajnal, "Optimization of building operational cost in the preparation process of public investment project", In M. Hajdu (Ed.), Elsevier B.V.: Proceedings of the CC 2015, Creative Construction Conference, Kraków, Poland, 309-316, 2015.

6. P. Ilg, Ch. Scope, S. Muench, E. Guenther, "Uncertainty in life cycle costing for long-range infrastructure. Part I: leveling the playing field to address uncertainties", International Journal of Life Cycle Assessment, 22(2): 277-292, 2017.

7. ISO 15686-5:2008, "Buildings and constructed assets. Service life planning. Part 5: Life cycle costing".

8. A. Lewandowska, A. Noskowiak, G. Pajchrowski, W. Strykowski, A. Witczak, „Środowiskowa ocena cyklu życia modelowych budynków drewnianych i murowanych jako przykład zastosowania techniki LCA", Poznań: Wydawnictwo Instytutu Technologii Drewna, 2012.

9. M. Mirkovic, "The Impact of Failure Types in Construction Production Systems on Economic Risk Assessments in the Bidding Phase", Hindawi Complexity: 5041803, 2018.

10. E. Plebankiewicz, K. Zima, D. Wieczorek, "Quantification of the risk addition in life cycle cost of a building object", Technical Transactions 5: 35-45, 2017.

11. E. Plebankiewicz, K. Zima, D. Wieczorek, "Life Cycle Equivalent Annual Cost (LCEAC) as a Comparative Indicator in the Life Cycle Cost Analysis of Buildings with Different Lifetimes", MATEC Web of Conferences: 196, 04079, 2018.

12. E. Plebankiewicz, D. Wieczorek, "Multidimensional sensitivity study of the fuzzy risk assessment module in the life cycle of building objects", Open Engineering 8:490-499, 2018.

13. E. Plebankiewicz, K. Zima, D. Wieczorek, "Scenarios for Maintenance and Building Decommissioning in the Building's Life Cycle”, IOP Conf. Series: Earth and Environmental Science 222: 012015, 2019.

14. R. Ruparathna, K. Hewage, R. Sadiq, "Economic evaluation of building energy retrofits: A fuzzy based approach", Energy and Buildings 139: 395-406, 2017.

15. A. Sharma, A. Saxena, M. Sethi, V. Shree, "Life cycle assessment of buildings: a review", Renewable and Sustainable Energy Reviews 15(1): 871-875, 2011.

16. J. D. Silvestre, J. De Brito, M. D. Pinheiro, "Environmental impacts and benefits of the end-of-life of building materials calculation rules, results and contribution to a "cradle to cradle" life cycle", Journal of Cleaner Production 66: 37-45, 2014.

17. D. Wieczorek, "Fuzzy risk assessment in the life cycle of building object - selection of the right defuzzification method", In AIP Conference Proceedings, AIP Publishing 1978(1): 240005, 2018.

18. D. Wieczorek, „Modelowanie kosztów cyklu życia budynków z uwzględnieniem czynników ryzyka”, Praca doktorska, Kraków: Politechnika Krakowska, 2018.

19. D. Wieczorek, E. Plebankiewicz, K. Zima, "Model estimation of the whole life cost of a building with respect to risk factors", Technological and Economic Development of Economy 25(1): 20-38, 2019.

20. A. Zeliaś, B. Pawełek, S. Wanat, „Metody statystyczne: zadania i sprawdziany”, Warszawa: Polskie Wydawnictwo Ekonomiczne, 2002. 


\section{LIST OF FIGURES AND TABLES:}

Fig. 1. Membership functions of fuzzy numbers for input parameters - basic set

Rys. 1. Funkcje przynależności liczb rozmytych dla parametrów wejściowych - zestaw podstawowy

Fig. 2. Resulting distributions of membership for the LCC criterion - basic set

Rys. 2. Funkcje przynależności liczb rozmytych dla parametrów wejściowych - zestaw podstawowy

Table 1. Data accepted for LCCA analysis

Tabela 1. Dane przyjęte do analizy LCCA

Table 2. Results of the verification of the model for estimating the total cost of the building life using the LCNPV method

Tabela 2. Wyniki sprawdzenia modelu szacowania całości kosztów życia budynków metodą LCNPV

Table 3. Results of the simulation of the impact of changing the value of temporal and financial input data on the calculation results

Tabela 3. Rezultaty symulacji wpływu zmiany wartości danych wejściowych czasowych i finansowych na wyniki obliczeń

Table 4. Result values for the LCC and LCEAC criteria depending on the choice of the set of membership functions and the method of defuzzification

Tabela 4. Wartości wynikowe dla kryteriów LCC i LCEAC w zależności od wyboru zestawu funkcji przynależności oraz metody wyostrzania

Table 5. Result values for the WLC and $\Delta \mathrm{R}_{\mathrm{LCC}}$ criteria depending on the choice of the set of membership functions and the method of defuzzification

Tabela 5. Wartości wynikowe dla kryteriów WLC i $\Delta \mathrm{R}_{\mathrm{LCC}} \mathrm{W}$ zależności od wyboru zestawu funkcji przynależności oraz metody wyostrzania. 


\section{AUTORSKI MODEL SZACOWANIA CAŁOŚCI KOSZTÓW ŻYCIA BUDYNKÓW I JEGO WERYFIKACJA}

Slowa kluczowe: cykl życia, całość kosztów życia, koszty cyklu życia, ryzyko, dodatek kosztowy za ryzyko, budynek

\section{STRESZCZENIE:}

Model szacowania całości kosztów życia budynków umożliwiający kwantyfikację dodatku kosztowego za ryzyko, pozwala inwestorowi porównać budynki na wstępnym etapie planowania przedsięwzięcia budowlanego pod względem następujących kryteriów ekonomicznych: kosztów cyklu życia budynku (LCC - gdy inwestor nie będzie mógł notować przychodów); całości kosztów życia budynku (WLC - gdy oprócz ponoszenia kosztów w fazach cyklu życia budynku, inwestor będzie mógł notować również przychody); ekwiwalentu rocznych kosztów cyklu życia budynku (LCEAC gdy długości trwania fazy eksploatacji będą różne); dodatku kosztowego za ryzyko w cyklu życia budynku $\left(\Delta \mathrm{R}_{\mathrm{LCC}}-\right.$ wyrażonego jako różnica w jednostkach walutowych pomiędzy wielkością kosztu cyklu życia budynku, która uwzględnia wpływ ryzyka, a wielkością kosztu cyklu życia budynku, która nie uwzględnia tego wpływu). W modelu, teoria zbiorów rozmytych łączona jest z najbardziej powszechną, dynamiczną metodą służącą do analizy efektywności ekonomicznej przedsięwzięć budowlanych na podstawie zdyskontowanych przepływów pieniężnych. Jest to metoda wartości bieżącej netto, zwana pod akronimami NPW (ang. net present worth) lub NPV (ang. net present value), która w modelu ma zastosowanie w wersji rozmytej (ang. fuzzy NPW lub fuzzy NPV).

Dane wejściowe do modelu dzielą się na następujące parametry: czasowe CG (o charakterze globalnym), tj. czas trwania cyklu życia budynku $T_{i}$, przy czym $T_{i}$ równy jest szacowanemu okresowi użytkowania budynku (ESLB - ang. estimated service life of a building); czasowe CL (o charakterze lokalnym), czyli czasy $\mathrm{t}_{\mathrm{ik}}, \mathrm{t}_{\mathrm{im}}$, po których naliczane zostają odpowiednio k-ty okresowy koszt operacyjny lub m-ty okresowy przychód; finansowe FG (o charakterze globalnym), w postaci stopy dyskonta (r), która jest niezbędna do obliczenia wartości bieżącej netto danej kwoty pieniężnej w oparciu o jej wartość określoną w czasie przyszłym; finansowe FK (rozumiane jako koszty mogące zaistnieć w cyklu życia budynku), wśród których wyróżnia się koszty o charakterze rocznym - roczne koszty operacyjne $\left(\mathrm{C}_{\mathrm{opA}, \mathrm{ij}}\right)$ oraz okresowym - kolejno koszty początkowe $\left(\mathrm{C}_{\mathrm{in}, \mathrm{i}}\right)$, okresowe koszty operacyjne $\left(\mathrm{C}_{\mathrm{opNA}, \mathrm{ik}}\right)$ i koszty wycofania $\left(\mathrm{C}_{\mathrm{wd}, \mathrm{i}}\right)$; finansowe FP (rozumiane jako przychody mogące zaistnieć w cyklu życia budynku), czyli przychody o charakterze rocznym - roczne $\left(\mathrm{I}_{\mathrm{opA}, \mathrm{il}}\right)$ oraz okresowym - kolejno okresowe przychody uzyskiwane w fazie eksploatacji budynku $\left(\mathrm{I}_{\mathrm{opNA}, \mathrm{im}}\right)$ i przychody osiągnięte $\mathrm{w}$ fazie wycofania $\left(\mathrm{I}_{\mathrm{wd}, \mathrm{i}}\right)$. Do parametryzacji wymienionych powyżej danych wejściowych w modelu użyto wypukłych i normalnych liczb rozmytych.

Celem niniejszego artykułu jest natomiast sprawdzenie poprawności działania modelu szacowania całości kosztów życia budynków umożliwiającego kwantyfikację dodatku kosztowego za ryzyko na ewentualność zmiany parametrów mogących wpływać na wyniki obliczeń. Zakres badań obejmuje: porównanie wyników wygenerowanych przez model z wynikami uzyskanymi przy wykorzystaniu deterministycznej metody wartości obecnej netto w cyklu życia (LCNPV ang. life cycle net present value) dla danych wejściowych czasowych i finansowych nieobarczonych wpływem ryzyka; analizę zmienności wyników na skutek zmiany danych wejściowych; analizę zmienności wyników na skutek zmiany zestawów funkcji przynależności dla danych wejściowych oraz metody wyostrzania wyniku.

W artykule zaprezentowano przykład obliczeniowy ekonomicznej analizy cyklu życia LCCA (rozdział 3.1). Przykład dotyczył porównania trzech alternatywnych rozwiązań budynku mieszkalnego wielorodzinnego, które wynikają z konieczności uwzględnienia wpływu oddziaływania zidentyfikowanych czynników ryzyka w jego cyklu życia $\left(Z_{1}-\right.$ błędy w projektach i $Z_{2}$ - błędne założenia rozwiązań konstrukcyjno-materiałowych). Przykład ten stanowił również podstawę do przeprowadzenia szeregu badań weryfikacyjnych i analiz wrażliwości modelu. 
W rozdziale 3.2 model został poddany sprawdzeniu deterministyczną metodą wartości obecnej netto w cyklu życia (LCNPV). Sprawdzenia dokonano pod kątem zbieżności wyników generowanych przez model z wynikami uzyskanymi przy wykorzystaniu metody LCNPV.

W rozdziale 3.3 omówiono wyniki analizy wrażliwości modelu poprzez badanie wpływu zmiany wartości danych wejściowych czasowych i finansowych na wyniki obliczeń generowanych przez model. W badaniu wykorzystano propozycję normy ISO 15686-5:2008 („Budynki i budowle. Planowanie okresu użytkowania. Część 5: Koszty cyklu życia”) i przeprowadzono symulację wyników dla ekonomicznych kryteriów porównawczych LCC, LCEAC, WLC i $\Delta \mathrm{R}_{\mathrm{LCC}}$ dla wybranego scenariusza cyklu życia alternatywnego rozwiązania budynku z przykładu przedstawionego $\mathrm{W}$ rozdziale 3.1. Przyjęto następujący zakres zmian związanych $\mathrm{z}$ parametryzacją danych czasowych $\mathrm{i}$ finansowych $\mathrm{w}$ stosunku do danych przyjętych pierwotnie do analizy LCCA dla scenariusza $i=2$. Wartość stopy dyskonta $(r)$ uległa zmianie o $\pm 1 \%$ (z około $8 \%$ do około $7 \%$ i około 9\%). Długość cyklu życia $\left(\mathrm{T}_{2}\right)$ zmieniono o \pm 5 lat (z nie więcej niż 60 lat do odpowiednio nie więcej niż 55 lat i nie więcej niż 65 lat). Wielkość kosztów początkowych $\left(\mathrm{C}_{\mathrm{in}, 2}\right)$ przyjęto ze zmianą o $\pm 10 \%$ (z nie więcej niż 7333700 PLN do nie więcej niż 6600330 PLN i nie więcej niż 8067070 PLN), a wielkość kosztów operacyjnych $\left(\mathrm{C}_{\mathrm{opNA}, 230}\right)$ - również ze zmianą o $\pm 10 \%$ (z nie więcej niż 1090000 PLN do nie więcej niż 981000 PLN i nie więcej niż 1199000 PLN).

W rozdziale 3.4, dla danych czasowych oraz finansowych, które w przykładzie obliczeniowym (rozdział 3.1) zostały zamodelowane jako wielkości niepewne, dokonano zmiany podstawowego zestawu funkcji przynależności na pozostałe alternatywne komplety funkcji, tj.: alternatywny I (złożony z funkcji odcinkowo kwadratowych; alternatywny II (utworzony przez funkcje harmoniczne); alternatywny III (zbudowany z funkcji Gaussa). Przyjęto również założenie o sprawdzeniu wyników dwoma metodami wyostrzenia, tj. metodą środka ciężkości (CoG) lub metodą równoważenia obszaru (AC - ang. area compensation). Dla każdej z 84 kombinacji (po 8 przypadków dla kryteriów LCC, LCEAC i WLC oraz po 4 przypadki dla kryterium $\Delta \mathrm{R}_{\mathrm{LCC}}$ ) obliczono ostre wartości wynikowe. Otrzymane wyniki stabelaryzowano podając wartości: średniej arytmetycznej (m); odchylenia standardowego (s); współczynnika zmienności (V).

We wnioskach (rozdział 4) wykazano, że model szacowania całości kosztów życia budynków umożliwiający kwantyfikację dodatku kosztowego za ryzyko wygenerował w pełni zbieżne wartości wynikowe dla kryteriów porównawczych LCC, LCEAC, WLC i $\triangle$ RLCC, dla wszystkich scenariuszy cyklu życia budynku z rezultatami otrzymanymi w drodze obliczeń deterministyczną metodą LCNPV. Badanie wrażliwości modelu na ewentualność zmiany wartości danych wejściowych czasowych i finansowych na wyniki obliczeń wskazało na te parametry finansowe - stopę dyskonta $(\mathrm{r})$ oraz koszty początkowe $\left(\mathrm{C}_{\mathrm{in}}\right)$, w przypadku których zmiany wartości $\mathrm{w}$ zakresie przewyższającym odpowiednio $\pm 1 \%$ dla $(\mathrm{r})$ oraz $\pm 10 \%$ dla $\left(\mathrm{C}_{\mathrm{in}}\right)$, będą wpływać istotnie na wartości wyników dla kryteriów ekonomicznych. W przypadku badania wrażliwości modelu na ewentualność zmiany parametrów wpływających na wyniki obliczeń, maksymalna wartość współczynnika zmienności wyniosła $\mathrm{V}_{\max }=1,73 \%$, a zatem w żadnym z analizowanych przypadków, wartość V nie przekroczyła 10\%. Na podstawie uzyskanych wyników stwierdzono, że wszystkie parametry mogące mieć wpływ na wyniki, wskazują na nieistotne zróżnicowanie wartości wynikowych dla wszystkich ekonomicznych kryteriów porównawczych (LCC, LCEAC, WLC i $\Delta \mathrm{R}_{\mathrm{LCC}}$ ). Badanie wrażliwości modelu szacowania całości kosztów życia budynków potwierdziło bardzo wysoką jednorodność generowanych wyników.

Received 15.04.2019, Revised 30.04.2019 